proposed, for recreational uses, not only by the inhabitants of the larger cities of the State, but also by the country people and the inhabitants of the smaller towns whose home surroundings are often oppressively monotonous; $(b)$ to consider the uses of forests as preserves of the primitive life of the State, of great interest and value to the student of science and his teacher and to the lovers of wild life; $(c)$ to co-ordinate the forest policy of the State with the movement for the establishment of a system of State parks.

A study of this manual and the appendices may be recommended to all interested in the progress of afforestation in Britain and in the development of a. forest policy on sound lines.

\title{
Mountain-Building Movements and the Genesis of Petroleum.
}

\section{By Henry B. Milner.}

' $\mathrm{HE}$ influence of mountain-building movements on oil migration and accumulation has long been recognised, and is so plainly manifest in different petroliferous provinces all over the world, that it has become one of the least controverted theories in the general hypothesis of oil occurrence. In the past decade, the teachings of the Alpine school in Europe have especially helped to clarify this relationship, and developments in the oilfields of Galicia, Rumania, Traq, Persia, Burma (to cite only a few) are constantly impressing us with its significance.

An unorthodox, and to some extent novel, aspect of the matter is viewed by $\mathrm{Mr}$. John $\mathrm{L}$. Rich in a paper entitled "Generation of Oil by Geologic Distillation during Mountain-Building," 1 in which he follows more or less similar ideas put forward by Bailey Willis some years ago. He starts off with the fact that in regions of intense mountain-building movements, carbonaceous shales are seen to have lost their 'kerogen' or oil mother-substance, such hydrocarbon, however, being present in equivalent rocks without the metamorphic zone. The destiny of this "lost' petroleum is traced in accordance with the latest theories of orogenesis, though not entirely by stages usually recognised in this particular natural history.

Rich defines at the outset his geosyncline, with its accumulation of thick series of bituminous sediments under deposition (conventionally) in a sinking basin. The next phase is mainly orogenic, concerned with the piling up of thrust-sheets over (the italics are mine) the geosynclinal sediments, this accompanied by a kind of synclinorial folding of the sediments beneath the nappes, further by the inevitable iso-

${ }^{1}$ Bull. Amer. Assoe. Petroleum Geologists, vol. 4, pp. 1139-1149; 1927. static sinking. During this stage oil is generated by heat and dynamic movements, apparently beneath the nappo zones, the environment simulating that of a " giant high-pressure cracking still." There follow successively peneplanation and further unwarping of a regional character, and finally the delineation of three distinct zones. Zone $\mathrm{l}$ is the zone of distillation, i.e. intense dynamic metamorphism, where the bituminous rocks have suffered devolatilisation, carbon ratios are high, and possibly only small quantities of gas remain. Zone 2 is the zone of partial distillation, and what Mr. Rich calls in situ accumulation. In this zone the rocks are partly devolatilised, carbon ratios are medium, and oil is plentiful. In Zone 3 the unaltered rocks occur, and the influence of active dynamic distillation has not been felt; consequently carbon ratios are low, oil is scarce, and what there is of it has probably migrated either during orogenic movement or afterwards in response to hydraulic factors.

Thus it will be gathered that the author arrives at the explanation of this type of oil-pool in a somewhat different manner from that often given; also, he ascribes considerable importance to the upwarp phase, when rocks formerly subjected to distillation are exposed to inflow and artesian circulation of meteoric waters, causing extensive secondary migration of the oil. This putting of 'the cart before the horse' is probably the most contentious part of the theory. On the other hand, if there is anything in the hypothesis, then contiguous deposits to areas of carbonaceous shale occurrences, given the requisite evidence of earth-movement on a large scale, should be worth inspection for oil, undoubtedly an invigorating prospect. The author cites the Oklahoma-KansasMissouri-Towa region as his example; possibly the reader may call to mind another.

\section{Herring Food.}

$\mathrm{D}^{\mathrm{r}}$

R. P. JESPERSEN, in an important memoir, gives a detailed account of the food of the herring in Danish waters " Investigations of the food of the Herring in Danish Waters," Meddelelser fra Kom. missionen for Havundersøgelser. Serie: Planton. Bind 2, No. 2, 1928. Copenhagen). This was undertaken at the instigation of the International Council for the Investigation of the Sea, and is part of a general scheme for working out the biology of the herring in different countries of Northern Europe.

The research is based on the examination of the stomach and intestine contents of a large number of fishes at different stages of development, with special reference to the diet during growth from larva to adult, noting variations in the nature and quantity of the food in different waters and at different seasons. More than 7000 fishes were examined, nearly 3000 of which were young stages between $4 \mathrm{~mm}$. and $50 \mathrm{~mm}$. in length, the remainder being adolescent and adult.

The results of the examination of the larval and young stages agree with former observers. It is found that those retaining the yolk are able to feed, although there is less food (chiefly green remains) inside them, in proportion to their size, than in the post-larve. After the absorption of the yolk sac much more food is taken, the size and amount of food increasing with the size of the fish. Phytoplankton and very small zooplankton is found in the smallest fishes, larger copepods and other small planktonic animals in those of larger size. Copepods predominate, especially Temora longicornis and, next in importance, Pseudocalanus and Paracalanus. The young herring $6-17 \mathrm{~cm}$. in length, feed largely at all seasons, chiefly on copepods, but also at times on cladocerans, polychætes, Sagitta, and appendicularians. The adult herring $17-30 \mathrm{~cm}$. in length, feeds mainly on Crustacea, but there is a considerable variation in its food according to season and locality. In the breeding season herring eggs are often eaten. In most localities, as has been shown by previous workers, spawning herring as a rule do not eat, although occasionally one finds full herring and those actually spawning with a large amount of food inside. Here they have been found to contain a considerable quantity of food,

No. 3072 , Vor. 122] 
especially the mature spawning herring. The young herring eat more than the adults ; the relative number eating is greater and also the average number of organisms eaten per herring. The food varies in the herring from the four localities investigated. It is striking that no euphausiids, important as herring food elsewhere, find a place amongst the food of the Danish herring.

The whole work shows clearly that different food is eaten in different localities and different seasons, that different-sized herrings eat different sorts of food, and that adolescent herrings eat more than the aduits. Also that copepods as a whole are the most important organisms in the food of the herring from Danish waters.

This memoir embodies a very large amount of work clearly stated, and is a most valuable addition to the literature rapidly accumulating on the biology of the herring.

\section{Genetics of 'Bar-eye' in Drosophila.}

THE allelomorphic series of mutations in Drosophila

known as bar-eye and ultra-bar have been much investigated owing to their variability in the number of ommatidia present. It has been shown, for example, that increasing temperature $\left(15^{\circ} \mathrm{C}\right.$. to $31^{\circ} \mathrm{C}$. ) causes a decrease in the number of facets which is of an exponential or linear order; and that this rate of decrease is more rapid in bar than in full eye, and most rapid of all in ultra-bar. Flies which are heterozygous for any of these genes are intermediate in mean facet number between the corresponding homozygous parents developed at the same temperature; but they approach more nearly to one parental condition than to the other, so that one of the conditions may be considered dominant. Near $27^{\circ} \mathrm{C}$. is a critical temperature at which change of dominance takes place. Others have shown that at or near this temperature, growth and rate of development both cease to be accelerated. A rise in the frequency of crossing-over in the second chromosome has also been shown to take place at about this temperature, as well as the maximum amount of muscular contraction from a certain stimulus.

These results indicate that some general protoplasmic reaction is involved. More recently, Mr. A. H. Hersh (Jour. Exptl. Zool, vol. 47, No. 2) has shown that in crosses of the bar series the Mendelian dominance differs in the reciprocal crosses as well as with the temperature at which the larvæ were reared, $27^{\circ} \mathrm{C}$. being a critical point. He concludes that the cytoplasm of the egg plays some part in determining the size of the eye. Unlike reciprocal hybrids have long been familiar in Enothera, but very few cases have been described in animals. It is suggested that characters in general may form a series with a few at one end determined solely by the cytoplasm, many at the other end determined wholly by the nuclei, and some between, such as the bar series, determined partly by both.

In another paper (Jour. Exptl. Zool., vol. 50, No. 2) Mr. Hersh has analysed further the bar series. Zeleny showed that the compound eyes of such flies have a dorsal and a ventral lobe, which also shows in flies with full oval but mosaic eyes. Such bilobing is common in Diptera and oceurs in other insects. Mr. Hersh shows that in the bar series, with increasing temperature, the number of facets in the ventral lobe decreases faster than in the dorsal lobe, and suggests that the optic stalk forms the line of separation between the two lobes. It is concluded that the genes of the bar eye series produce their effects by altering the distribution of growth in the developing organism:

\section{University and Educational Intelligence.}

London.-The Connaught Hall of Residence (14 Bedford Place, W.C.1), recently presented to the University by His Royal Highness the Duke of Connaught, will be ready for students of any of the colleges and "schools" of the University at the opening of the session in October.

Thr University College of Wales, Aberystwyth has established a Travelling Scholarship Fund which is used for the purpose of enabling members of the staff and students to visit foreign countries for the purpose of extending their studies. The grants made are quite small, generally $£ 10$, but are, the Council reports, greatly appreciated. Last year seven members of the staff, three past students, and forty students received such grants.

" Accredited Higher Institutions," a pamphlet issued as Bulletin, 1927, No. 41, by the United States Bureau of Education, shows that in the absence of any central controlling authority a fairly complete system for standardising educational institutions has been evolved by voluntary associations. It gives lists of institutions of higher education accepted by certain national and regional associations as meeting their standard requirements. Most of these requirements are set out in full, as are also the college, junior-college, and teacher-training college standards of the American Council on Education, which took the initiative in formulating standards for general adoption in accrediting institutions, but is not itself an accrediting agency. The other associations are : the Association of American Universities, five regional (Middle, Southern, North Central, North-Western, and New England) Associations of Colleges and Secondary Schools, the American Associations of Junior Colleges and of Teacher-Training Colleges, and a number of professional associations. Of fully accredited professional schools there are 71 medical, 26 dental, 53 pharmacy, 65 law, and 15 librarianship.

The Council of the City and Guilds of London Institute has recently issued a report for 1927 - the forty-eighth annual report since its incorporation. Of its three departments, namely, the City and Guilds (Engineering) College at South Kensington, the City and Guilds South London Technical Art School, and the Department of Technology, the first, which is the largest of the three colleges constituting the Imperial College of Seience and Technology, was attended during the year by 506 students. Notwithstanding the continued depression of the engineering industries, the number of entries to the college is maintained, thanks to anticipations of a growing demand in the near future for electrical engineers. Of the 188 candidates for admission, 34 (more than twice as many as in the preceding year) came from schools outside Great Britain: 23 were from India. A very large proportion of the students, nearly 40 per cent, were scholarship holders, the total sum awarded by external authorities to students during the session being £16,346. Post-graduation classes in electrical engineering, the value of which has been recognised by industrial firms, increased notably, and 14 students were awarded the post-graduation diploma of the Imperial College. Since the formation of the Imperial College Appointments Board, 728 engineering students have been registered, of whom, so far as is known, only 17 are unemployed. 